\title{
On the Exposition of the Transformation of Commodity-Values into Production Prices in the Third Volume of Capital-A Textual Analysis
}

\author{
Jørgen Sandemose \\ IFIKK, University of Oslo, Oslo, Norway \\ Email: jorgen.sandemose@ifikk.uio.no
}

How to cite this paper: Sandemose, J. (2016) On the Exposition of the Transformation of Commodity-Values into Production Prices in the Third Volume of Capital-A Textual Analysis. Theoretical Economics Letters, 6, 962-985.

http://dx.doi.org/10.4236/tel.2016.65098

Received: August 4, 2016

Accepted: September 17, 2016

Published: September 20, 2016

Copyright $\odot 2016$ by author and Scientific Research Publishing Inc. This work is licensed under the Creative Commons Attribution International License (CC BY 4.0).

http://creativecommons.org/licenses/by/4.0/

\section{(c) (i) Open Access}

\section{Abstract}

The article is about the exposition of the Karl Marx's concept of production prices in his main work Capital. It focuses on the structure of the central text in question, Chapter 9 of the third volume, on "transformation [Verwandlung] of commodityvalues into production prices". The actual content and structure of the chapter has to some degree been overlooked or distorted in the literature. The aim of the article is to establish (or re-establish) a sound view of the chapter, freed from prejudices nurtured by-especially - a theory of price formation which, albeit "modernized" by i.a. Walras, dates back to Steuart and Ricardo. These prejudices have had an immense significance for misunderstandings of the Marxian theory of measure of value and standard of prices reflected in the text of the chapter mentioned. For this reason, the article is furnished with an Appendix, underlining the difficult situation for Marxistminded research today. It should be noted that it is not an objective of the article to discuss any extant interpretation of Marx's exposition. However, the paradigm of criticism that was introduced early in the $20^{\text {th }}$ century by Ladislaus von Bortkiewicz is used as a perspective. Specific references-other than to Marx's own texts-are held at a minimum in the article proper. I have chosen such a mode of approach because I find that misunderstandings of the chapter are evenly distributed among authors regardless of how their views on the "transformation" collide. On the other hand, such a consciousness of "misunderstandings" among commentators certainly does imply that the author should at least shortly clarify his own view of the main problems in the paradigmatic criticism mentioned above. In the first section, I point out the importance of Marx's way of presenting his concept of the composition of capital. In the next, I make some remarks on the concept of the socially necessary labour time and its relation to abstract labour. In the third and fourth, I investigate Marx's different models of analysis. In the fifth section, it will be shown how Marx, contrary to contentions of traditional criticism, but in harmony with his treatment of the 
capital composition and necessary labour time, is operating with a double point of departure: He treats the inputs of a production period as given as values, i.e. as individual use value-entities; paralleling this, he treats them as transformed to production prices. There follows a sixth section, where I point out the core of the critique that Bortkiewicz presented of the chapter, focusing on the need for a uniform expression of economic denominations. Since Bortkiewicz's criticism contained all the important germs to the objections against Marx refuted in my article, this section also serves to spread light over the rest of my argument. After the overview mentioned above, I round off with a summary.

\section{Keywords}

Values, Prices, Transformation, Organic Composition, Weighted Average, Scientific Method

\section{The Role of the "Organic Composition of Capital"}

In spite of endless discussions, the significance of the fact that Chapter 9 of Capital III starts with the definition of the organic composition of capital (OCC), is mainly overlooked. As he did in his main chapter on accumulation, in Volume I (where the concept was introduced for the first time), Marx in this text underlines the dual character of that composition: Some shortenings and symbols will be used (Please see Abbreviations)

The organic composition of capital depends, in each actual moment, firstly, on the technical relation between the labour power employed to the mass of means of production employed; secondly, on the price of these means of production. As we have seen, it must be considered in its percentual relation. The organic composition of a capital that consists of $4 / 5$ constant and $1 / 5$ variable capital, we express through the formula $80 c+20 v$ ([1], p. 164).

For the purpose of giving an immediate illustration of such an individual capital, let us reproduce the form of one of the industries which Marx investigates a little later in the chapter, where he is operating with an aggegate of capitals with the average composition of $78 \mathrm{c} / 22 \mathrm{v}$. A stipulated depreciation on fixed capital is included (cf. the difference between the sum of the first two columns $(80+20+20=120)$ and 90 as a "commodity value"). The cost price (70), i.e. the owner's actual expenses in producing the commodity, is added to an unchanged mass of surplus value (20), so that the result $(70+20)$ yields an equivalent to the product value of 90 , which is then modified to a price of 92 , since the capital in question is (slightly) above-average (Table 1).

To return to the OCC: As one can imagine, the weight that Marx puts on the technical composition, reflects the main definition made in Volume I, where he says that in order to express the interaction between use value and value, he "will call the value composition of capital insofar as it is determined by its technical composition and reflects its changes, the organic composition of capital" ([2], p. 640, italics added). This 
Table 1. Transformation to production price in a single branch.

\begin{tabular}{ccccccc}
\hline $\begin{array}{c}\text { Capital } \\
\mathrm{I}\end{array}$ & $\begin{array}{c}\text { Surplus } \\
\text { value }(s)\end{array}$ & $\begin{array}{c}\text { Commodity } \\
\text { value }\end{array}$ & $\begin{array}{c}\text { Commodity } \\
\text { cost price }\end{array}$ & $\begin{array}{c}\text { Commodity } \\
\text { price }\end{array}$ & $\begin{array}{c}\text { Rate of } \\
\text { profit }\end{array}$ & Deviation \\
\hline $80 c+20 \mathrm{~V}$ & 20 & 90 & 70 & 92 & $22 \%$ & +2 \\
\hline
\end{tabular}

should be compared to a passage in one of his drafts, where the following, striking definition is given:

The organic composition can be understood as follows: Different relation, in which outlay in constant capital is necessary in the different branches of production to absorb the same mass of labour. The connection of the same volume of labour with the object of labour requires either more raw materials and machinery in the one case than in the other-or only in one of both" ([3], pp. 379-80).

Thus, the $O C C$ is a category meant to analyze the basic relation of exploitation in capitalism, where the means of production are set in motion with the sole purpose of sucking labour out of the immediate producers. This labour is measured not solely as abstract labour pure and simple, but simultaneously as the SNLT contained in each product.

Marx introduced the $O C C$ as a foundation for his analysis of accumulation, i.e., precisely at the point where he declares that he wants to "investigate the influence which the growth of capital has on the destiny of the working class" ([2], p. 640). This "destiny" is dependent on the degree to which labour is sucked out of the individual worker, as well as on the rate of unemployment and of pauperism. Obviously, then, it is no accident that the $O C C$ is placed right at the start of this "transformation" chapter. Analysis of the genesis of the "transformation" to the capitalist price system is certainly no secondary matter. The absorption of labour time, and its subsequent division amongst capitals, is its central theme.

Consequently, it cannot surprise anyone that Marx should look for a magnitude, $S N L T$, which goes back to the quantification of concrete labour in any process of production. To this $S N L T$, there corresponds technical exigencies that cannot be separated from it. The whole of the actual labour time in each of the different branches (stored in the commodities' $c$-, $v$-, and $s$-parts) has to be presented explicitly in the analysis, which is precisely what happens when Marx tells us that the organic composition "we express through the formula $80 \mathrm{c}+20 \mathrm{v}$ ", where the randomly chosen numbers represent values. Taken as a price equal to the value, it gives the exact expression of the proportion. In this way, it makes sense to say, i.e., that a given capital "consists of $4 / 5$ constant and $1 / 5$ variable capital".

\section{Double Character of the Socially Necessary Labour Time}

Although the $O C C$ was not thematized as such prior to the main chapter on accumulation, its inner structure, going back to the difference between value and use value, and thus abstract, respectively concrete labour, is present from the beginning of Capital.

${ }^{1}$ Henryk Grossmann [4] has presented the thoroughgoing double character of the economic categories by Marx in an important work. 
Insofar, the point of departure lies in the unity of value and use value in any commodity: Since labour is the substance of value, and time the measure of this labour, we know that the measure cannot be perceived in itself, but only as it appears in a material thing. That being so, it follows immediately (i.e., rather, it is given beforehand) that this thing has to stand (rather: it stands) in relation to another thing, a commodity (or several of them), to express itself as what it is.

Another case in point is Chapter 5 in Capitals first volume, "Process of labour and process of valorization", where the capitalist production is analyzed partly as a general process of labour, partly as a process of valorization and creation of value. Here, the "raw material is just something that absorbs a given quantity of labour" ([2], p. 204). This happens because all means of labour are here conceived as means of absorbing that very labour, and labour itself consequently as the expression of a labour power which exists only to be absorbed. The actual labour performed must function in accordance with the $S N L T$, which is "the labour time which counts as value-creating" ([2], p. 204). But that cannot mean that $S N L T$ in itself has a logical extension identical with that of abstract labour, for it is a phenomenon valid only for the labour process inside a given branch at a time, and has not got the universality of the abstract. It (merely) counts as value-creating, as Marx points out. One should note that Marx is careful to use such a conditioned terminology. For example, in Chapter 10 of Volume III of Capital, analyzing the same branch-structure that we meet in Chapter 9, he underlines that it is a condition that "the quantity of labour present in a commodity represents socially necessary labour time" ([1], p. 191, italics added). This of course implies that abstract labour and $S N L T$ are taken to indicate the same numerical quantity, but at the same time, it is implied that they are two different phenomena.

It is a fact that Marx describes labour in capitalist production as being of a double character. it is both abstract and concrete (cf. [5]).

There are problems related to this expression. One is accustomed to talk about capitalist industrial labour as either abstract or concrete, but one is not always willing to think through the implications that arise when it is presupposed that one and the samelabour has both characteristics. A closer analysis, not to be pursued here, is required to understand how a labour operation takes on such a contradictory form ${ }^{2}$. However, it is more than likely that the $S N L T$ is the "labour" in question. It is natural to presume that it denotes a technically determined entity, albeit only to the extent that technology can be employed as an absorber of a labour in general (abstract labour). It is consequently an entity which results from an interaction between something abstract and something concrete, and this comes clearly to the fore in the OCC. SNLT should be considered as that character of concrete labour which, together with the potentiality of labour of being a simple and average magnitude, is the entity from which the abstraction named "abstract labour" is done; this last operation, in its turn, has to be present in

${ }^{2}$ Let it only be mentioned that the need for a precise definition might well lay behind Marx's persistent, but not well rounded, work on the category "productive labour". Here, his original aim of writing specificlyon "Lohnarbeit", might also have been of significance. 
the mind of the worker himself: It is actually an increment in the labour process (cf. [6], esp. Section 5.5, pp. 276-277).

\section{Marx's Methodological Presupposition of an ITC}

Now, as regards the transformation procedure, not only has the presence of the $O C C$ definition, and its implication for the interpretation of the $S N L T$, generally been overlooked, but so has also the context of the illustration that Marx then presents to us ${ }^{3}$. In his exposition (cf. [1], p. 166), the procedure is illustrated through the following schema:

It is characteristic of the misunderstandings of Marx's point that it has in practice not been seen that this illustration from the outset is not describing a set of producers reflecting a social total, but five randomly constructed industrial branches. This means that the author is not necessarily presupposing that the branches make up any social system of production. Thus, it is clear that the level of analysis is quite another than the one that meets us in the reproduction schemes of the second volume of Capital ([8], pp. 351-520).

The contrary view was introduced by Bortkiewicz in his well-known first critical article, second part, printed in 1907 ([9], p. 15 sq.). It was kept live and kicking by Paul M. Sweezy in his endorsement [10] of both articles, and has later haunted the literature. It is one of many totally unwarranted interpretations of essential points in the Marxian corpus, interpretations that could scarcely have arisen at all if one had bothered to subject his writings to a serious scrutiny ${ }^{4}$.

Let us look closer at the evidence. Marx's starting point is explicitly as follows: "Let us take five different branches of production, each with different organic composition of the capitals invested in them" [1], p. 164). As he goes along, he presupposes that the five "capitals" make up one "total capital" (cf. 1, pp. 165, 166, 169), that is, one firm, an ITC, an individual total capital. This, too, is something quite different from a social total. (All the more so since Marx here seems to be sliding from thinking of branches as such, to presupposing individual capitals in a branch-perhaps its average exemplar.)

At first, this concept of ITC is introduced together with a table which is somewhat less complicated than Table 2, since the difference in depreciation is not brought up. When he goes over to argue for the necessity of operating with different depreciation rates in the illustration, Marx does in fact not soften the ITC model; and as soon as the argument is made, he goes on to "consider ... the capitals I - V once again as a one individual (ein einziges) total capital" ([1], p. 166). Indeed, although he speaks of prices through the whole of the paragraph in question ([1], pp. 166-167), and actually defines

\footnotetext{
${ }^{3}$ This also goes for Fine and Saad-Filho [7], where the "transformation problem" is taken up in their Chapter 10. Here, the authors say that in the transformation, Marx makes use of the OCC "exclusively", the technical and value compositions being of less interest. Simultaneously, they treat the value composition as if it makes another index superfluous. But in that case, there would be no difference between the two kinds of composition. The authors in fact make no attempt to substantiate their thesis.

${ }^{4}$ The need for such a scrutiny is the reason why I have chosen to use the original German edition when making direct references to Marx's works.
} 
Table 2. Transformation to production prices in an ITC as a randomly collected set of branches.

\begin{tabular}{cccccccc}
\hline & Capitals & $\begin{array}{c}\text { Surplus } \\
\text { value }\end{array}$ & $\begin{array}{c}\text { Value of } \\
\text { commodities }\end{array}$ & $\begin{array}{c}\text { Cost price of } \\
\text { commodities }\end{array}$ & $\begin{array}{c}\text { Price of } \\
\text { commodities }\end{array}$ & $\begin{array}{c}\text { Rate of } \\
\text { profit }\end{array}$ & $\begin{array}{c}\text { Deviation } \\
\text { of price } \\
\text { from value }\end{array}$ \\
\hline I & $80 \mathrm{c}+20 \mathrm{v}$ & 20 & 90 & 70 & 92 & $22 \%$ & +2 \\
II & $70 \mathrm{c}+30 \mathrm{v}$ & 30 & 111 & 81 & 103 & $22 \%$ & -8 \\
III & $60 \mathrm{c}+40 \mathrm{v}$ & 40 & 131 & 91 & 113 & $22 \%$ & -18 \\
IV & $85 \mathrm{c}+15 \mathrm{v}$ & 15 & 70 & 55 & 77 & $22 \%$ & +7 \\
V & $95 \mathrm{c}+5 \mathrm{v}$ & 5 & 20 & 15 & 37 & $22 \%$ & +17 \\
\hline
\end{tabular}

the price of production in the midst of this setting, he does not presuppose the immediate functioning of a market.

In the definition, Marx primarily stresses the importance of the rates of profit of the separate branches, which, as he says, are " $=s / C$ in each branch of production, and must be developed from the value of the commodity" ([1], p. 167, italics added). These separate rates are, he continues, the basis for the ARP. The branches where they are to be found, are characterized by reciprocal differences as regards their "organic composition" ([1], p. 167). All in all, this can be seen as evidence that Marx is here focusing on the importance of the technical composition of capital in making up the OCC, since to imply that the quantity of abstract labour ("the value") of the commodity is a basis, implies that the $S N L T$, and thereby also the $S N L T$ considered as concrete labour, is decisive in constructing the basis of the rate $s / C$ and mediately therefore also the $A R P$. The latter is a result of competition between branches with specific $s / C$ 's, Marx says ([1], p. 167).

Strictly speaking, this reference to "competition" is the only hint in Marx's text so far of the existence of a factual $S T C$ - a capital comprising all industrial entities in society, in so far as they are based on wage labour. As can easily be agreed upon, competition (between capitals) is an impossible concept in the analysis of what goes on inside an ITC.

We may look at these facts as hints of what comes to happen in the following paragraph, for there Marx actually passes over to talk of "the total capital of society in all spheres of production taken together" ([1], p. 168), implying that the market now is at the center of the realities analyzed. He underlines that all these "different capitalists here behave, insofar as the profit is considered, as pure stockholders in a joint stock company". He stresses their role as a social class opposed to workers, and that the profit of each is appropriated in abstraction from the individual $O C C$, and just as "pure parts of the total social capital".

Nevertheless, Marx in the following paragraph reintroduces the original position: "Let us presuppose that the five investments I-V belonged to one man" ([1], p. 169). Here, the existence of a capitalist class is being compared and partly identified with an ownership relation including only one single individual. Marx concludes the paragraph and the comparison as follows: 
And in this way, in society itself-the totality of all branches of production-the sum of production prices of the produced commodities is equal to the sum of their values ([1], p. 169).

All in all, it seems that despite apparent contradictions, and even intermingling of two different models of illustration, it remains clear that this Marxian (Marxian-Engelsian?) text at no point has opened for the necessity-nor, in fact, the possibility-of analyzing the genesis of the production price through reproduction models of the total social capital. Such models, Marx seems to hold, must be made up with inputs and outputs which are not only determinable in principle, but actually can be set up numerically with proportions that are taken to be known and specific. Such a model is presented in the last part of Volume II of Capital ([8], pp. 351-520).

In the context of the transformation, the ITC serves to focus on the concept of $S N L T$ taken as a concrete labour time $e^{5}$. As such, Marx may have meant it to function as another justification for presenting inputs as values. Inside a single capital, the market is not present in any immediate way. Inside such a model, prices are susceptible to be identical to values. A similar kind of presentation can be found in Chapter 1 of Volume I, when Marx employs labour time as an indicator of the magnitude of labour in noncapitalist structures.

\section{The Structure of The STC}

In fact, it is also possible to find a "turning point" in Chapter 9, showing us the limits of the presentation of an ITC. This occurs when Marx is summing up the genetic factors of the $A R P$ itself. There are two such factors. The first one works "through the organic composition of the capitals in the different spheres of production, i.e. through the different rates of profits of the individual spheres" ([1], p. 172). It depends directly on the concept of the intraspherical relation which we recognize as $s / C$.

But secondly, and simultaneously, Marx now introduces the weighted average, a phenomenon belonging to the interspherical competition, a factor working

through the distribution of the social total capital on these different spheres, i.e. through the relative magnitude of capital allocated in each specific sphere, and consequently to a particular rate of profit: i.e. through the relative mass-proportion of the social total capital which each particular sphere of production absorbs (verschluckt) ([1], p. 172).

Such a distribution of capital involves directly the $S T C$, and in itself makes it meaningless to operate further with illustrations limited to an ITC. If a certain development inside of $S T C$ results in masses of capitals pouring into a low-composition branch, swelling up relatively the parts of $S T C$ invested in such industries, this will result in a lower $A R P$, pressing down the social average $O C C$ even without changing the $O C C$ in the sphere itself.

${ }^{5}$ In [11], we find Marx making an implicit distinction between concrete and abstract labour time. Cf. [11], 313. Furthermore, his use of the expression "pure labour time" $([11], 701)$ indicates the same distinction. 
The $I T C$-illustration is used by Marx as long as each capital in the different branches has the same total $c+v$. Introducing the weighted average, he gives up any such "model".

Nonetheless, the text ensuing from Marx's treatment of the genetic factors mentioned, leads us into a de facto argument for the plausibility of constructing tables starting with inputs in the form of value magnitudes. This happens through his introduction of the concepts of branches with "mean", "higher", and "lower" organic composition ([1], p. 173sq).

Marx sets up three different capitals, one of them with an exact mean composition, to illustrate. It would be a mistake to believe that this is done in order to form an image of an "average" capital as an auxiliary for the process of measuring prices, as Marxisant proponents of any eventual Bortkiewicz-minded solution might be apt to think. As we shall see, there is no use for such a device by Marx. Rather, the illustration serves (as the text shows) to underline a thesis to the effect that in each branch, there is constantly formed a market value, corresponding to the $S N L T$ per commodity. Under the new circumstances, where "the production price has been developed as a transformed form of the commodity value" ([1], p. 173), any capital representing the branch average, and thus the value of each actual product of the branch, gets its product value transformed to a price by the intervention of the $A R P$ (cf. [1], p. 174). Such is the accurate measure of the price of production of the branch. This is nothing but a logical consequence of the point of departure, designed already in the first chapter ([1], pp. 33-50, "Cost price and profit"), which operates with commodity-values as cost-prices, and it serves to underline how that starting point is consciously followed up by Marx. However, characteristically, the author immediately discloses that the starting point has a double character, as we shall see presently.

\section{Marx's Presupposition of Transformed Inputs}

Rounding off the three-branches illustration, Marx writes:

On the other hand, in employing these denominations (Bezeichnungen) in specific cases, it must of course be considered whether there is in fact no difference in the technical composition present, and if it is a pure change in value of the elements of the constant capital that leads to a divergence from the general average between $c$ and $v([1]$, p. 174).

This passage shows the eminent importance of the technical side of the $O C C$, and consequently of its double character. Also, it seems that the way of posing the problem fully confirms the theory here put forward about Marx's intentions. Indeed, one might even suspect that the $O C C$-definition was originally formulated with situations like these in mind. What Marx points out, is the existence of divergences between the $S N L T$, as a determinate product-value in relation to others, and the "value" (price) which this "product-value" has got as a consequence of the transformation to production prices ${ }^{6}$. Also, the $S N L T$ seems here to be considered precisely as a function of the

${ }^{6}$ As is well known by readers of Marx, "product-value" designates both value and use value of the total product of a capitalist production period. 
technical composition. No wonder that Marx's text immediately goes on with a well-known remark on the real character of cost-prices. He says that "[t]hrough the development given here ... a modification is introduced as regards the determination of the cost price of commodities" ([1], p. 174), since "the production price of the commodity is ... its cost-price for its buyer, and consequently can enter as cost-price in the price formation of another commodity" ([1], p. 174) ${ }^{7}$ In consequence, he can speak of "the possibility of an error if a cost-price of a commodity in any particular sphere is identified with the value of the means of production consumed in its production" ([1], p. 174).

The reference to such an "error" has, again and again, been taken to imply a self-criticism, or a self-contradiction, in Marx's text. We see now that the context shows that the "error", on the contrary, is so to speak constitutive for Marx's way of posing the very problematic of the transformation. It follows from its double point of departure, and from the divergence between values and production prices of "elements of the constant capital". Furthermore, Marx goes on in some detail to show how any given "commodity price of production" inside a branch can change (1) as a consequence of an exogeneous change in the $A R P$, and (2) from an endogeneously given "technical change" and/or a "change in the value of the commodities entering as construction elements (Bildungselemente) in its constant capital" ([1], p. 175). He follows up with a longer overview of "macro" phenomena related to changes in the $A R P$ (cf. [1], p. 176). From here, the last few pages of the chapter ([1], pp. 177-181) analyze the ideological result, and how "the practical capitalist must be totally incapable of cognizing the inner essence and shape (Gestalt) of this process" ([1], p. 178).

As we have seen, the $O C C$ lies at the bottom of the transformation process: The technical composition illustrates the structure needed for sucking labour time out of workers. This can only happen through SNLT, corresponding to measurement in values of every single commodity. On the other hand, we saw that the value composition, in abstraction from the technical one, is connected to "the price of these means of production" ([1], p. 164, italics added). This means, again, that we have to consider the "inputs" in question in two different ways, which both have to come to the fore in the analysis.

As Marx makes clear, if we call the rate of profit in a particular sphere $s / C$ (surplus value related to total capital in the sphere), this rate has to be "developed from the value of the commodity". He goes on, saying: "Without this development, the general rate of profit (and consequently the production price of the commodity) remains a senseless, notionless presentation" ([1], p. 67).

It is clear, then, that Marx must reject any "solution" of the transformation process

${ }^{7}$ There are some linguistic problems here. Marx says verbatim: "Der Produktionspreis einer Ware ist aber für den Käufer derselben ihr Kostpreis..."([1], 174). The last genitive is misplaced in any interpretation of the sentence. It should be clear what is meant. Moreover, the consecutive passages in Marx's text have been misinterpreted in other regards. I have commented on this in an earlier work (cf. [9], p. 47). The matter is not important in the present case, because all we need here, is evidence that Marx in fact does think of cost prices as expressed through (different sets of) production prices. The difficulty is omitted in the next quote I bring from Marx's text. 
which does nothing more than to operate with both inputs and outputs measured in production prices. To accept such a way of thinking would mean ending up in a system of equations with no determined solution, and with no theoretical foundation in labour time.

On the other hand, it seems difficult to accept a "solution" that could be taken to imply that some commodity-elements of particular capitals are sold at their values, that is, at the value-price (an expression in money which quantitatively coresponds with precision to their $S N L T$, i.e., having the same relation to the total mass of $S N L T$ in the system as its price has to the total of commodity-values of that system) while others are sold at their production price. This is a contradictory structure, and conceptually it follows naturally from the presupposition of "inputs" being measured in values, while "outputs" are being measured in production prices. Consequently, it has in practice acted as an argument against Marx's view of the transformation.

The tradition has never been able to produce evidence that Marx ever thought along lines that could be broken by such a criticism. In fact, as can be seen from our exposition, he consciously assumes that inputs as well as outputs exist in the form of production prices. On the other hand, it should be conceded that this feature of Marx's construction of Chapter 9 points to a weakness in the way the ITC is introducedin the chapter: It should have been underlined stronger that the reader has to think of it as a unit not buying or selling anything outside itself. For else, the fact that its commodities may well be seen as composed of cost prices or production prices, could indicate that those prices originated on the outside market.

That the general, structural argument of the chapter has been overlooked, seems due partly to the fact that the essence of its method has escaped readers. What Marx described, was how a certain volume-let us call it $X$-of $S N L T$, distributed on three entities, namely on the material (use value) contents of constant capital, variable capital and surplus value $(c+V+s)$ (of any produced commodity) respectively, is transformed-through the intervention of an $A R P$-into a mass of commodities distributed in three similar aggregates, each with a corresponding production price denomination (cf. [12], esp. pp. 49-52).

To clarify, let us recapitulate the one branch of Table 1.

\begin{tabular}{ccccccc}
\hline Capital I & $\begin{array}{c}\text { Surplus } \\
\text { value }(s)\end{array}$ & $\begin{array}{c}\text { Commodity } \\
\text { value }\end{array}$ & $\begin{array}{c}\text { Commodity } \\
\text { cost price }\end{array}$ & $\begin{array}{c}\text { Commodity } \\
\text { price }\end{array}$ & $\begin{array}{c}\text { Rate of } \\
\text { profit }\end{array}$ & Deviation \\
\hline $80 c+20 \mathrm{~V}$ & 20 & 90 & 70 & 92 & $22 \%$ & +2 \\
\hline
\end{tabular}

In the example, the production price of the commodity corresponding to $80 c+20 v+$ $20 s$ (note that each aggregate is denominated in $S N L T$ ), is 92. According to this setup, we are free to stipulate a production price of the "inputs", that is, the same material components $(80 c+20 v)$, multiplied with what we have called the "price indicator", a specific quantitative value-price relation, e.g. as $75 c \pi+25 v \pi$, or e.g. $78 c \pi+25 v \pi$, etc. Any further changes are due to a presupposed, determinate change in the level of the $A R P$. 
A decisive point, making up a sharp contrast to the traditional criticism of Capital III, 9, is that neither the magnitude of the aggregate $X$, nor the magnitude of its subaggregates, need to be known in the analysis. What is important, is that we know that all $X$-entities do have some definite value magnitude, in the sense that it is in principle evident that this magnitude is an objective and given quantity. This presupposition once made, we can illustrate the case with any numerical entities for $S N L T$ that we may want to employ, maintaining the adequate proportions in the table. Similarly, we may introduce other numerals to illustrate a relative magnitude of aggregates as measured in production prices. The important thing is, again, that we know that the commodities in the given aggregates of $X$ must be in possession of a production price denomination. This is evident enough, since we are treating a transformation from distinct SNLTaggregates to $\pi$-aggregates, where the $S N L T$ is distributed in new proportions. As we have seen, what Marx does, is (at least) in line with these methodological presuppositions.

It should be clear enough that inside such a scheme, it has got no specific meaning to make analyses of equilibria or disequilibria before or after a transformation. Technically, the main reason for this is the impossibility of calculating the accurate content of $S N L T$ inside an aggregate like $X$, not least because this aggregate-as Marx clearly implies-in actual, enpirical fact meets us as a constellation of production prices. Neither have Marx's critics ever produced a convincing argumentation underpinning the necessity of any such calculus. In the precedent volumes of Capital, Marx has succeeded in showing that there must exist exactly determinable quantities of value (and $S N L T$ ) inside any aggregate in the capitalist economy. In Volume III, he has shown how these quantities can be thought of as equally accurately determinable quantities of production prices.

The chapter, however is, however, badly organized. While it seems only natural to refer to the problematic character of the cost price where we have now seen it done, Marx in fact introduces the theme much earlier, namely after his first mention of the STC ([1], p. 169). This category he introduces by way of analogy with the five branches in the setup (i.e. taken as intra-firm "branches"), not through any calculation based on numerical proportions in those branches. This background in the intra-firm illustration then leads Marx to remark that his way of presentation "seems to contradict ... that the elements of the productive capital as a rule are bought on the market, so that their prices contain a realized profit ... that is, that the production price in one industrial branch pass into the cost price of another" ([1], p. 169).

Whatever the contextual mess, that sentence obviously cannot (as has been supposed in the literature) be meant as a self-criticism of Marx's own use of value magnitudes in the scheme. Such a view would seem to presuppose an ignorance of the context of the illustration. On the contrary, the remark is meant to underline the difference between relations inside a firm (such as the one used in the illustration) and relations on the market. After having made that clear, Marx goes on to say that "if we place the sum of the cost prices of a country on one side, and the sum of its profits or surplus values on 
the other, then it is clear that the account will get right" ([1], p. 169). In other words: He thinks that total prices must be equal to total values as a matter of course.

Concretely, he argues by presupposing that a given commodity has a cost price in which there may enter a number of profit magnitudes with provenance from products delivered from producers of the means of production whose commodities are consumed in the production of the commodity in question, taking part in the adding up of its price. The sum of these profits Marx calls p. He continues:

[If] a profit $\mathrm{p}_{1}$ is addedto this cost price, then the total profit is $\mathrm{P}=\mathrm{p}+\mathrm{p}_{1}$. The total cost price of the commodity, abstracted from all price parts representing profit, is then its own cost price minus $\mathrm{P}$. If this cost price is called $\mathrm{k}$, then evidently $\mathrm{k}+\mathrm{P}=$ $\mathrm{k}+\mathrm{p}+\mathrm{p}_{1}([1], \mathrm{p} .170)$.

Marx exemplifies the dynamics at work here by saying that it is clear enough that the product of a capital, called B, will diverge from its value. Surprisingly, he says that this is because the realized surplus value in B will diverge from the profit added (through the $A R P$ ) (cf. [1], p. 170). The language indicates that Marx is thinking of the individual capital $\mathrm{B}$ as a producer who has gone through an intra-branch competition, and "realized" a surplus value that is average in the branch (i.e., $=s / C$ ), relatively to the mere magnitude of capital.

Marx then adds that the divergence alluded to between value and (production) price goes not only for the products of $\mathrm{B}$, but also for "the commodities which make up the constant part of capital B, and also [make up] its variable part, indirectly, as the workers' consumer goods" ([1], p. 170).

He explicates this in some detail, which, for our purposes, it is unecessary to comment. (Still, the substance follows below, for other reasons.) The above is sufficient to show that Marx actually does precisely something which his more or less ardent Bortkiewician critics claim that he does not do: He is describing what the critics treat as a "left hand side" of the equation as products which are-as regards their price magnitude-built up by production prices.

\section{An Overview}

This review of the actual structure of Chapter 9 has been necessitated by the fact that the formal as well as the real objections made against the text for more than a century, have missed central points to a remarkable degree. As a consequence, it is necessary here to make a few remarks on the most important misapprehension, which has overdetermined most of the ohers.

This relates to Bortkiewicz's thesis that for Marx, "value is simply an index for an exchange relation" [13]. For him, this implied that a specific commodity functions as such an index, and this commodity he [13] calls the "measure of value and prices" ("Wert-und Preismass"), presuming it to be simultaneously money as well as an object of exchange.

Now, this leads Bortkiewicz to contend that a change in the value (or price) of a 
given piece of this "index" would lead to (intricate) changes in whole spectrum of relative prices in the socio-economic system. The model here was Ricardo's thesis on the connection between wages, commodity prices and composition of capitals. However, Bortkiewicz ignored that Marx identified the concept of money with the concept of circulation. For Marx, a change in the price of the money material would not affect relative prices. The reason is that the value of commodities are necessarily expressed in the material of the (money) commodity. A "relative price" of a commodity is thus nothing but an imagined physical weight of gold. Consequently, Ricardo's view that one needs a medium-composition capital as a basis for measuring rods for the economy, is obsolete. The crux of the problematic was pointed out by Marx in Theories of SurplusValue, in criticising Ricardo's well-known thesis to the effect that certain movements of prices of commodities depend on the composition of capital in the money commodity industry (cf. [14], p. 29):

... here we have got to do with Ricardo's false presupposition that money, inasmuch as it serves as means of circulation, is exchanged as commodity against commodity. [On the contrary:] The commodities are evaluated in it before they circulate ([3], p. 198).

Furthermore, in exposing his theory of circulation, Marx says: "It is ... quite clear that a change in the value of gold does not, in any way, affect its function as a standard of price" ([2], p.113). He also remarked, in a note to the second edition of Capitals Volume I:

With English writers the confusion between measure of value and standard of price ('standard of value') is indescribable. Their functions, and therefore their names, are constantly interchanged" ([2], p. 113).

The fact that this Marxian theory of money has scarcely been discovered by any "Marxist", is embarassing. The criticism in question is relevant not just against Bortkiewicz and early followers like Sweezy (not to speak of marginalist criticism of Marx), but even against the "new solution" of the so-called transformation problem, as put forward by e.g. D. Foley, R. Wolf, B. Roberts and A. Callari, not to speak of the "temporalist" ("TSSI") treatment of the matter in question. (Cf. [6], Section 6.)

In fact, the problem in question was dissolved by Marx already in 1859, writing in his Critique that

nothing can be more erroneous than the idea that gold and commodity inside the circulation process pass into a relation of immediate barter, so that their relative value is shown (ermittelt) through their exchange as simple commodities ([15], p. 72 ; italics in the original).

It follows that as regards the "transformation problem" in its strict sense, any system of simultaneous equations is irrelevant. Such models have been introduced into the discussion because one has taken any change in the price of the material of the money commodity to lead to changes in the whole system of relative prices. However (taking 
gold to be the material in question), a change in the price of a given piece of gold as a consequence of the transformation, will lead only to a new level of total prices, while there will be no change in the relative prices. Any change in the actual number used in denominating the price of a given piece of gold, will lead to nothing more than a (nominal) change in the denomination of the total universe of prices (the general price level).

What has presently been underlined concerning Marx's theory of value and money, concerns the reason why one can safely regard the inputs in his transformation scheme as given entities, not necessitating any re-calculation to prices. It also explains, as a matter of course, why there is no doubt that the total sum of prices equals the total sum of values, and that the sum of value added equals the sum of "prices added" (implying that the much debated problem of "the two totalities" in the transformation is obsolete).

All this is closely connected with what is said above on the necessity of the commodity-value to be immediately expressed in another commodity, and thus in its material. That value thus comes to life only in its opposite, a material use value, is the root of the double character of all "economic" categories by Marx. As we have seen, this in its turn makes it comprehensible that Marx introduces an ITC-model. Still, since this is done without any clearly formulated reason, the reader is de facto presented to a situation where it would indeed have been appropriate to think of "value" simply as an "index". For this is of course the consequence when one uses examples that do not involve circulation, nor money, as is the case with the ITC.

Circulation is present, however, in the $S T C$-model. Here, money circulates commodities, and there is strictly speaking no excuse for Bortkiewiczian blunders. What is circulated, are commodities as products of $S N L T$, and the circulation itself stands for their transformation to products with production prices. This is described quite rationally by Marx, since his tables operate with the SNLT's of the elements of $c$ and $v$. These are elements of the cost price that are physically existing at the start of the production period. Their (value) magnitude is therefore capable of being transferred to the finished product by the concrete aspect of the new $S N L T$-labour added to them in the period. This magnitude, as well as the physical bodies bearing them, must ever be present in the product after the transformation, and the way it is transferred must be part of the explanatory model; therefore, so must the SNLT-magnitudes of the original inputs.

On the other hand, the reader's understanding of these analytical necessities can easily be blurred by the fact that Marx-apparently-takes very light-handedly on the question of the status of variable capital. The methodological point of departure, namely the identification of value and cost price, he describes (as we have pointed out above) as a situation where "the cost price of a commodity is identified with the value of the means of production consumed in its production" ([1], p. 174). This unduly leaves out the piece of the physical mass which represents variable capital, i.e. the material counterparts to the prices/values of labour power; it is obviously just a slip, but has lead to confusion. 
To illustrate the point, let us use a number of rows (A, B, and $\mathrm{C}$ ) divided into identical parts of labour time. Each part represents 4 hours.

(A)

\begin{tabular}{|c|c|c|}
\hline$a$ & $b$ & $c$ \\
\hline 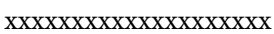 & 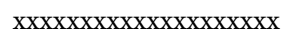 & 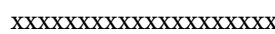 \\
\hline
\end{tabular}

A represents the product value of a certain product of a capitalist labour process. The contrast (colour) indicates concrete labour. Thus, we have to do with a product of 12 hours of labour. In principle, it might illustrate such a product even of a non-capitalist process.

If we look at this same product solely in relation to its existence as a result of a capitalist process of valorization, we get:

(B)

\begin{tabular}{|c|c|c|}
\hline$c$ & V & $s$ \\
\hline xxxxxxxxxxxx & & \\
\hline
\end{tabular}

The rate of surplus value is $=1$. The working day is 8 hours. An amount corresponding to 4 hours of value is produced in the former period of production, i.e. it consists of old value transferred from the means of production-machinery and raw materials. As long as the product is seen under the value aspect alone, the $v+s$ can represent solely abstract labour. Those symbols are there not because they represent $\mathrm{b}+$ c (which, incidentally, they in fact do), a concrete labour, but because this concrete labour is also abstractlabour. On the other hand, $c$ is present solely because it represents $a$; as a value magnitude, it is there solely because it has been transferred by four hours of concrete labour. In terms adjusted to capitalist relations and to Marx's terminology, $c$ $+v+s$ represents the "product value" of the process, while $v+s$ represents the "value product".

Let us now look at a third figure:

(C)

\begin{tabular}{|c|c|c|}
\hline$c$ & $V$ & $s$ \\
\hline 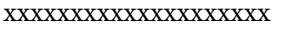 & 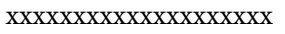 & \\
\hline
\end{tabular}

In $\mathrm{B}$, variable capital is present solely as a magnitude of values. But in $\mathrm{C}$, both the $c$ and the $v$-parts are considered as concrete labour. This is done only to denote a situation where the capitalist has paid for commodities that are actually present. We recognize the structure of the cost price: $c$ represents outlay for means of production, but these means are also concretely in action as material entities; $V$ represents variable capital, but also actually working labour power. 
Seen from the standpoint of C, $s$ seems to be the only new value present, and consequently susceptible of being ascribed to the whole of the rest of the capital indiscriminately. In fact, this is the way the category of the "rate of profit" actually emerges. An important genetic factor is that while the wage in capitalism is necessarily paid post factum (because the worker owns no means of production and consequently is bound to give credit to the capitalist, who on his part need not have any means to use as payment before after the sale is done), the continuous processing of production makes it appear that labourmight as well be paid in advance. After the first production period of a given capital, the wage form is steadily reproduced again and again.

In the first chapter of the volume, Marx points out that " $t]$ he investigation will ... show that in the capitalist economy, he cost price acquires the false show of being a category of value production in itself" ([1], p. 37). This is the case here. However, the real situation is captured by $\mathrm{B}$ above: The new value is always the magnitude $v+s$. What appears as the new value, however, is just $s$. In that form, it is accepted in the guise of an ARP. (See the development in Table 2). The variable capital figuring in the cost price is the wage for the previous period of production ${ }^{8}$.

Thus, it seems to belong to the weaknesses of the chapter that it is composed as if Marx here and there is himself forgetting the true, inner connection. In any case, his exposition should have been amended by some references to the first chapter of the volume, especially to his own argument to the effect that variable capital cannot enter the construction of new value (cf. [1], p. 38).

Holding on to $\mathrm{C}$ above, it there appears as if the $A R P$ is the true form which is uniting different branches. Marx says of the capitalist that " $[\mathrm{h}]$ is cost prices are specific. The profit added to this cost price is independent of his specific branch of production" ([1], p. 169). The $A R P$ is so to speak the representative of the truly abstract labour, the abstraction made from the $S N L T$ of the branches. Simultaneously, it brings with it the nature of money, since its existence implies circulation and thereby an "exchanging" between branches. Of course, this way of thinking belongs to the imagination, but nevertheless, the illustration is quite adequate-as soon as one does not forget that the abstract labour is always there, since, as we have seen, production prices can take part in the "price formation" of other commodities (cf. [1], p. 174). Not to mention that one should keep in mind that it obviously was a primary intention by Marx to point to this fact!

\section{Conclusions}

Most of the debate on Marx's argument concerning the transformation of values to

${ }^{8}$ The illustrations (A, B, C) used in this section have a special bearing on the problems relating to the fact that the ways of existence of variable capital apparently are internally contradictory. To avoid misunderstandings, it should be added that this author finds it probable that some set of simultaneous equations will be very helpful when it comes to presenting the social reproduction of capital in a way that clarifies those movements specific to variable capital. It is clear, however, that such equations should then be integrated in an input-output-analysis that does not imply any necessity of presenting the product of any branch equal to 1 , something which, as implied above, would mean a misunderstanding of Marxian money theory. Consequently, the equation-set would escape problems traditionally leading model-builders to postulate an exogeneous variable. 
prices has - to a varying degree-a background in the provisional character of the ninth chapter of Volume III. That being so, a report of the obscurities and ambiguities that are present should be presented prior to any material criticism of its content.

I hope that this article has made it reasonably clear that the expositional problems in the chapter are of a formal character. It is not improbable that if Marx had put more work into making a chapter readable, any Bortkiewiczean criticism would have been refuted by professional connoisseurs at an early date.

The chapter, as it stands in Engels' construction from Marx's original texts, contains a couple of instances of slippery use of terms (on realization of commodity values, and on the nature of the elements of the cost price) that Marx should have eliminated as notoriously false.

In addition, it goes for the text in general that the connection between the paragraphs is not very clear. Also, certain concepts, like "branch" (Produktionssphäre) remain ambiguous. Still, all of this does not amount to much. More importantly, Marx's illustrative models are not kept adequately separate from each other, inviting confusion. Nonetheless, a general order is recognizible here: Granted the dual point of departure, the text gives us a "two steps in one"-exposition: the ITC-model is employed for demonstrating the necessity of accounting cost prices as values, while the more "realistic" STC-model is used where the actual structure of the surface of the economy, and the appearance of cost prices as (and constructed through) production prices, is to be shown. All in all, even in this sense, Marx is in line with the promise he gives in the introduction to the very first chapter:

The concrete shapes (Gestaltungen) of capital, as they are being developed in this book, consequently step by step are closing up on the form in which they present themselves on the surface of society, in the action of capitals on each other, in competition, and in the common consciousness of the agents of production themselves ([1], p. 33).

Still, it is difficult to escape the conclusion that the extant lack of clarity has served as an excuse for an usatisfactory reading of Chapter 9, as well as for a criticism that is not quite fair. Marx's basic theory of the double character of categories, especially of the organic composition of capital, has not been apprehended at all. Furthermore, this last has led critics to try to justify precisely the theory of price formation which was the primary object of Marx's own criticism. Such attempts even seem to have been the motive force of the Bortkiewicz-inspired critique. It may have been overlooked that unfortunately, the "surface of society" invites us to superficialities.

\section{References}

[1] Marx, K. (1968) Das Kapital. Dritter Band. Europäische Verlagsanstalt, Frankfurt.

[2] Marx, K. (1968) Das Kapital. Erster Band. Europäische Verlagsanstalt, Frankfurt.

[3] Marx, K. (1968) Theorien über den Mehrwert. Dritter Teil. Europäische Verlagsanstalt, Frankfurt.

[4] Grossmann, H. (1968) Marx, die klassische Nationalökonomie und das Problem der Dy- 
namik. Europäische Verlagsanstalt, Frankfurt.

[5] Marx, K. (1970) Letter to Engels, 24.8.1867. Marx-Engels Werke, 31, 326.

[6] Sandemose, J. (2010) Fundamentals of a Science of Capital and Bourgeois Society: Marxian Notions of Value, Prices, and the Structure of Time. In: Zarembka, P., Ed., The National Question and the Question of Crisis, Research in Political Economy, Vol. 26, Emerald Group Publishing Limited, 253-299. http://dx.doi.org/10.1108/S0161-7230(2010)0000026009

[7] Fine, B. and Saad-Filho, A. (2009) Marx’s Capital. Pluto Press, London.

[8] Marx, K. (1968) Das Kapital. Zweiter Band. Europäische Verlagsanstalt, Frankfurt.

[9] Bortkiewicz, L.V. (1907) Zur Berichtigung der grundlegenden theoretischen Konstruktion von Marx im dritten Band des Kapital. Jahrbücher für Nationalökonomie und Statistik, 89, 319-335. http://dx.doi.org/10.1515/jbnst-1907-0118

[10] Sweezy. P.M. (1942) The Theory of Capitalist Development. Monthly Review Press, New York.

[11] Marx, K. (1953) Grundrisse der Kritik der politischen Ökonomie. Dietz, Berlin.

[12] Sandemose, J. (2004) The "Transformation Problem": Wage Form, Numéraire, and Value Transfer. International Journal of Political Economy, 34, 41-58.

[13] Bortkiewicz, L.V. (1906-1907) Wertrechnung und Preisrechnung im Marxschen System. In: Archiv für Sozialwissenschaftund Sozialpolitik, Bände XXIII and XXV, J. C. B. Mohr, Tübingen.

[14] Ricardo, D. (1969) The Principles of Political Economy and Taxation. Dent, London.

[15] Marx, K. (1972) Zur Kritik der politischen Ökonomie. In: Marx-Engels Werke, Vol. 13, Dietz, Berlin.

[16] Horverak, Ø. (1988) Marx's View of Competition and Price Determination. History of Political Economy, 20, 275-297. http://dx.doi.org/10.1215/00182702-20-2-275

[17] Wood, J.C., Ed. (1996) Karl Marx’s Economics: Critical Assessments I. Routledge, London.

[18] Sandemose, J. (1973) Transformasjonsproblem og verditeori. In: Elster, J., Ed., Marx $i$ dag [Marx Today], Gyldendal, Oslo, 37-79.

[19] Sandemose, J. (2001) The World as a Game in Sraffa and Wittgenstein: A Case Study in Modern Bourgeois Ideology. In: Zarembka, P., Ed., Marx's Capital and Capitalism; Markets in a Socialist Alternative, Research in Political Economy, Vol. 19, Emerald Group Publishing Limited, 173-231. (Original title in internal publication 2000, University of Oslo: "Language-Games and Production Equations") http://dx.doi.org/10.1016/S0161-7230(01)19008-5

[20] Ramos, A.M. (1998) Value and Price of Production: New Evidence on Marx's Transformation Procedure. International Journal of Political Economy, 28, 55-81. http://dx.doi.org/10.1080/08911916.1998.11643979

[21] Sandemose, J. (2016) Notes on the Unity of Logic and Materialism. Journal of Social Science Studies, 3, 44-66.

[22] Sandemose, J. (2004) On Phantasms. International Journal of Political Economy, 34, 63-66.

[23] Loranger, J.-G. (2004) Comments. The "Transformation Problem": Wage Form, Numéraire, and Value Transfer. International Journal of Political Economy, 34, 59-62.

[24] Loranger, J.-G. (2009) The Walrasian and the Marxian Numéraire: Its Link to Gold as a Variable Standard of Value. CEA 43rd Annual Conference, 28-31 May 2009, University of Toronto, Toronto. http://economics.ca/2009/papers/0782.pdf 
[25] Loranger, J.-G. (2011) The Value of the US Dollar in the Current Exchange Rate Crisis. Economists of Tomorrow 13th Conference of the Association of Heterodox Economics ( $A H E$ ), 6-9 July 2011, University of Trent, Nottingham.

[26] Yaffe, D. (1975) Værdi og pris i Marx’ Kapital. Modtryk, Århus. (Original n.d.)

[27] Sandemose, J. (1976) Ricardo, Marx og Sraffa. Rhodos, Gyldendal, Bo Cavefors, Copenhagen, Oslo, Lund. 


\section{Appendix: The Destinies of Articles}

Habent sua fata epistolae. The text published above has-so to speak-been used in experiments by the author. It has, in versions with minor variations, been sent to several would-be scientific journals as a try cloth, and for the most part been rejected on grounds I have found to be very clearly related to a lack of knowledge of the Marxian corpus, and specifically of Marx's theory of value, measure of value, and standard of prices. Things have happened that have been of a character deserving attention to ethics in scholarly circles; it seems to me that they also point very directly to a potential crisis in elementary theorizing on economy, and in theory of social science in general.

Two of the cases I have in mind are, however, of a special, less grave kind. In one instance, an open access journal accepted the article, based on two positive reviews, of which one added that some objections could be made. I asked for those objections, and since they did not appear, I decided not to publish. In the other case, one of the reviewers of History of Political Economy (HOPE) gave a reject vote since he thought there was no element of history of science in the text. This simply surprised me, since he obviously had overlooked the de facto discussion inside British classical economy since Petty on the status and role of the gold material. Curiously, another "less grave" incident was connected precisely to the HOPE, when this journal published an article by Øyvind Horverak, "Marx's View of Competition and Price Determination" ([16]) Here, the author expressly endorsed my standpoint on the "transformation problem", but nonetheless managed to report my argument as if it meant that gold "will be able to function as a price measure in that all other commodities are measured against its value, i.e., against different quantities, of the commodity" ([16], p. 286). This is obviously meaningless. "Price measure" is a category de facto not used by Marx ${ }^{10}$. Furthermore, "value" is scarcely the only form of a quantitative relation of a commodity! Even so, the main point is of course that the commodities are not measured against the value of gold, but against the material of gold, i.e., its use value, expressed in weight unities (cf. also [19], p. 228). The confusing of these determinations is, needless to say, the fundamental and pervasive feature of all bourgeois ("orthodox" or "heterodox") reading of Karl Marx's economic theory.

One can find at least one other general feature which marks out the structure of the "transformation" debate, lowering its level of seriousness. This is the tendency to use the very prejudice which forms the core of the discussion, while turning it into an argument for its being accepted. Many times, I have met the objection that reviewers simply have not been able to find the terms of measure that the author (myself) find feasible to use to characterize the "transformation examples" with which Marx operates; or to quote directly from an anonymous referee in 2014:

${ }^{9}$ Horverak's article [16] is reprinted in [17], i.e. John Cunningham Wood's edition Karl Marx's Economics: Critical Assessments I, Routledge 1996, pp. 106-128.

${ }^{10}$ For an overview of the actual occurences of such a term in the Marxian corpus, see [18], p. 54-55, note. 
I could not find a clear formulation of the author's position regarding the issue of the units of measure that Marx employs in the commented example.

Now, since a substantial part of the article is devoted to pointing out the meaning of the only two categories used by Marx in that connection, viz., "measure of value" and "numéraire" or "standard of prices", there is obviously something nonsensical in such a passage. Its occurrence must be attributed to the fact that in the wake of the discussion amongst Marxisant writers, there has appeared an overwhelming majority for the acceptance of Bortkiewicz's viewpoints. As a consequence, there has been formedmore or less unconsciously-a lot of new auxiliary expressions, of which many, in the course of time, has been accepted as being just as necessary as the Bortkiewiczian modification itself. The truth is that they may rather deserve exclusion from the field of science.

The most often occurring of these expressions presumably is "the money price" of a commodity. In the Marxian corpus, money price can mean only one thing, namely, the price of a certain physical volume (au fond, weight) of a commodity functioning as immediate money material. In other applications, it is just confusing, since a commodity's price in Marx is its value expressed in the money material ${ }^{11}$. Another term is "MELT (monetary expression of labour time)", an expression not in itself irrational (it is even used by Marx on one occassion), which, however, is misused in the debate as a surrogate for the measure of value, to the extent that authors actively ignore the content of the latter expression in Marx's work.

Similar examples are to be found in constructions of more complex auxiliary concepts, such as the insistence, mentioned above, that when Marx, in Chapter 9, is giving the reader a picture of a capital with an average $O C C$, he is de facto involved in a thought-experiment related to the Sraffian Standard Commodity. The author who most doggedly has ever presented such views, which-needless to say-are without any textual support in Marx, is probably Alejandro Ramos ([20]). In his article in question, Ramos also won acclaim for allegedly having traced up a certain Marxian text "omitted" by Engels, creating the impression that Engels had overlooked that the piece contained an exceptionally clear Marxian formulation of the concepts of cost-price and value. This contention, aiming at building up the view that Marx in the text was continuously striving to overcome a difficulty relating to the measure of value, is eclatantly wrong, since that precise formulation is available to any reader of the third volume of Capital, and has been so since Engels' edition in 1894 (Cf. also [9], p. 56, note 6). Nonetheless, commentators to this very day continue to use Ramos' "findings", persistently confusing the premises of the debate ${ }^{12}$.

In reality, and as can be implied from my article, there is no reason to think that

\footnotetext{
${ }^{11}$ In a polemical connection like this one, I might mention that being some time ago asked to act as a referee for a book edition, I made it clear that the only reason I had to reject the synopsis, was that the author used the expression in question without explaining it. The publisher, highly active in the field, did not allow me an interchange with the author, which could have made his meaning clear.

${ }^{12}$ For evidence concerning similar, untenable views held by among others Patrick Murray, Fred Moseley, Gert Reuten, Riccardo Bellofiore, and C. J. Arthur, see [21].
} 
Engels has behaved especially "biased" in any way during the editing of the parts of the Marxian manuscript relevant here. Most of the charges against him have their background in phantasies concerning what kind of text would have been feasible if Marx had adopted a Ricardian theory of values and prices.

An interesting case in point is a discussion I once had with Jean-Guy Loranger, in the wake of his "peer review" of my article "The 'Transformation Problem': Wage Form, Numéraire, and Value Transfer" [9]. This exchange was published in the pages following that article, and included my reply ([22]) to Loranger (cf. [23]).

Loranger's viewpoints were then reiterated by him in [23] and [25], without my reply being mentioned.

In [23] Loranger tried to expand on some points in his "Comment" ([21]). He will

demonstrate that the Walrasian numéraire is identical to the Marxian numé-

raire-this sounds elementary, but many economists would object.

And here, Loranger adds a note, which runs: "See for instance Sandemose 2004 and my comment (Loranger 2004)."

Now, as regards distinctive writings on this core of the "transformation problem", I do not know of other than myself (partial exception: see [26] below) having taken up the point in question, and I find it conspicuous that Loranger does not offer any more names ${ }^{13}$. All the more so as he repeats his arguments in the publication of 2011, in which text he refers to "Loranger 2004", without mentioning that article (nor mine, by the way) in his bibliography.

As to the argument that Loranger is trying to put forward, it is simply untenable, since it just consists in finding a symbol for "gold" (" $G$ ") and letting it enter the set of commodity equations without any explanation of how any material use value can occupy a place in that system without being priced. The existence of prices is what combines commodities in the system, but a commodity, in its function of measure of value, does not own a price, functioning only through its physical material. Such arguments were pointed out already in my comment [22].

Now, as to rejections of my article, some chilling means have been met with. One of the worst single cases was generated by a reviewer for a respected North American journal, who criticized the author (myself) for being without knowledge of the existence of the passage from ([1], p. 174) concerning Marx's thesis on the "possibility of an

\footnotetext{
${ }^{13}$ I launched the criticism of Bortkiewicz and Sweezy at a seminar arranged by Jon Elster at the University of Oslo in 1971, printed in the book mentioned in [18]. Similar viewpoints were produced by David Yaffe ca. 1974 (cf. [26], and my note in [27], p. 23. To illustrate the general situation in debates on advanced Marxian concepts, it could be noted that Fred Moseley (cf. note 11, above) once approached me concerning the quotes from Marx on numéraire and measure of value. Having pointed out to him the relevant pieces of text, I received a question from him as to whether I had found them just by myself, and if I had made the relevant combination 'on my own'. I gave him the necessary information, of course including that Yaffe had made the same points. Immediately thereafter, an endorsement of "David Yaffe" appeared on Moseley's home page. Furthermore, Moseley from the same time on has contended that Yaffe is practicing the same method as himself. That a scholarly interpreter like Yaffe should have accepted Moseley's views on the "transformation problem", sounds absurd. The case should serve as a reminder for editors and publishers to control their routines concerning quality assurance as regards Marxian economics.
} 
error" in identifications between specific sums of prices and of values. Since my text relating to that comment was identical to the one displayed here above (Section 5), I of course made a protest to the editor, a "full professor" of economy. He met me with a comment to the effect that he had to respect reviews put forward by colleagues bona fide. I received no explanation as to how a reviewer with the said manners could be supposed to be bona fide.

My saddening main point is that theoretical travesty is the rule rather than the exception in material debates related to the "transformation" theme. Quite in general, it should be clear that the Bortkiewicz-Sweezy view of Marx' theory is, with undebatable clarity, built on a fundamental misunderstanding of Marx, and, furthermore, on a break with elementary logic.

Clearly, even bourgeois science can muster advanced criticism of logical failures and methodological inconsistencies. If, for instance, an author proposed an article on Immanuel Kant's categories of the understanding, coupled with the contention that they had no correlation to the time-form of a capacity for intuition, then any referee would be justified in calling the text a piece of rubbish. But when it comes to a text whose content undeniably has more direct revolutionary repercussions, things change. In the scholarly world, a tendency prevails to deny the actual content of such a theory, even if the denial is conspicuously absurd-and especially if there is not only a question of political antipathies, but even of the possibility that a given kind of accounting actually implies certain political presuppositions-which it is easy enough to substantiate in the case of the "transformation". Today, the Walrasian numéraire and the Walrasian system of simultaneous equations are apparently self-evident building-stones for what is called economic "science". The faint at heart may even feel that the legitimacy of their whole profession is at stake if such "pillars" were removed.

The self-contradictory form of the argument used by the bona fideeditor mentioned corresponds, typically enough, to the self-contradiction of the formalism inherent in the economic models which should be criticized here. It is like "explaining" a given reality through nothing else but the existence of that reality itself. The Bortkiewicz-Sweezy criticism of Marx, and even Ricardo's confounding of his readers in "On Value", do not, nor can they, possibly explain what "value" or "price" is; nor are they compatible with any rational explanation of such themes. They only represent shrieking demonstrations of the desirability for spreading knowledge of the Marxian explanation of them.

However, as can easily be determined,"heterodox" bourgeois thinkers today stand as representatives of Marxist theory proper, in the eyes of readers, multitudes, and masses. So Marxists (whoever they might be-yourself, yours truly, or still others housing a desire to find a scientific base for revolutionary avtivity) are confronted by enormous difficulties with being heard.Thus there is no wonder if the most vivid and suggestive pictures of their situation may be found in their experiences with publishers that do not even shrink back from calling themselves "Marxist".

An example, in brief: The article above last year was submitted to a well known English-Language, "peer reviewed" journal focussing on "Marxist" viewpoints. It was 
accepted by several referees, but then rejected by the editor for (inter alia) "never coming to the point". A subsequent discussion with the editor led the latter to propose we debate the matter relating to Marx's fundamental economic concepts in an exchange of e-mails. I furnished him with all he asked me to present to him-definitions of exchange versus circulation, abstract labour, and other terms and things. Quite soon, the good editor simply pulled away from the whole adventure-explaining that my "comportment" was inadequate. That comportment amounted to a friendly explanation of my view of basic definitions.

Now, there are unwritten laws agains cracking down on reactions such as the ones I have brought forward in this Appendix. But that very fact, however justified its existence, may also operate as a cover for unjustifiable comportment. Indeed, it would be strange if that were not a problem of some dimensions. Perhaps the use of the open access system, standing in a certain opposition to traditional values of "journalism", might bring us something good here? Maybe it could present us with incitements not to write our referee reports with greater negligience than what we would dare to present in our epistles?

\section{Abbreviations}

\begin{tabular}{cc}
\hline ARP & Average rate of profit. \\
ITC & Individual total capital. \\
OCC & Organic composition of capital. \\
$\pi$ & Price indicator. \\
$S N L T$ & Socially necessary labour time. \\
$S T C$ & Social total capital. \\
\hline
\end{tabular}

\section{Submit or recommend next manuscript to SCIRP and we will provide best service for you:}

Accepting pre-submission inquiries through Email, Facebook, LinkedIn, Twitter, etc.

A wide selection of journals (inclusive of 9 subjects, more than 200 journals)

Providing 24-hour high-quality service

User-friendly online submission system

Fair and swift peer-review system

Efficient typesetting and proofreading procedure

Display of the result of downloads and visits, as well as the number of cited articles

Maximum dissemination of your research work

Submit your manuscript at: http://papersubmission.scirp.org/

Or contact tel@scirp.org 